\title{
Neural Cell Adhesion Molecules in Rat Endocrine Tissues and Tumor Cells: Distribution and Molecular Analysis*
}

\author{
G. LAHR, A. MAYERHOFER, S. BUCHER, D. BARTHELS, W. WILLE, AND M. GRATZL
}

Abteilung Anatomie und Zellbiologie der Universität Ulm (G.L., S.B., M.G.), W-7900 Ulm; and the Institut für Genetik der Universität zu Koln (D.B., W.W.), W-5000 Koln, Germany

\begin{abstract}
The adhesive properties of neural cell adhesion molecules (NCAMs) can be modified by alternative splicing of the primary transcript or posttranslational modifications. In the present study, we describe distinct forms of alternative splicing and posttranslational modification of the extracellular domain of NCAM of various endocrine tissues and derived tumor cells of the rat. Using an antiserum detecting the immunoglobulin-like domains of NCAM as well as a monoclonal antibody recognizing the NCAM-specific polysialic acid (PSA), we observed a similar staining pattern in adrenals, pituitary, and neoplastic endocrine cells. In endocrine tumor cells [pheochromocytoma (PC12), insulinoma (RINA2), and pituitary tumor cells $\left(\mathrm{GH}_{3}\right)$ ], NCAM immunoreactivity was most intense at contact sites between the cells. The immunocytochemical data were substantiated by results of in situ hybridization histochemistry. Specifically, higher levels of NCAM mRNA were detected in the adrenal cortex than in the medulla. In the
\end{abstract}

pituitary, NCAM mRNA was more abundant in the anterior and intermediate lobes than in the neural lobe. The sequence of NCAM mRNAs in endocrine cells was analyzed by polymerase chain reaction and $\mathrm{S} 1$ nuclease protection assays. We found that major exons 4-13 of the NCAM mRNA in endocrine tissues and related tumor cell lines were homologous to those in the brain. However, PC12, RINA2, and $\mathrm{GH}_{3}$ tumor cells; normal rat pituitaries; and adrenals contained different amounts of NCAM mRNA with an alternative extra exon, termed VASE (also called $\pi$ in mouse) between constitutive exons 7 and 8 . In addition, in pituitaries, we detected an alternative exon in splice site a between the constitutive exons 12 and 13 , termed $a_{15}$ with or without an AAG triplett. These sites are thought to be important for the adhesive properties of NCAM. Therefore, these results suggest that modifications of NCAM may be important for adhesive interactions in normal and neoplastic endocrine cells. (Endocrinology 132: 1207-1217, 1993)
$\mathrm{N}$ EURAL cell adhesion molecules (NCAMs) represent a family of cell surface glycoproteins involved in the autoadhesion between NCAM-expressing cells. The temporal and spatial patterns of NCAM expression in derivatives of the germ layers in developing vertebrates led to the hypothesis that NCAM-mediated selective adhesion plays a critical role in a number of morphogenetic events (1). While NCAMs are transiently present in a variety of tissues during embryonic development, NCAMs in the adult are found mainly in neural, muscle, and endocrine cells $(1,2)$. Three different major NCAM protein isoforms have been characterized. The two large NCAM isoforms, with apparent molecular masses of 180 and 140 kilodaltons, span the plasma membrane and contain large or small cytoplasmic domains, respectively. The small NCAM isoform (120 kilodaltons) is anchored to the plasma membrane via phosphatidylinositol (3-5). At least 20 major exons code for the different NCAM isoforms. The leader sequence is encoded by exon $\mathrm{O}(6-8)$. Exons 1-14 are used to generate the extracellular domain of all three polypeptides. Exon 15 codes for the membrane anchoring sequence of NCAM-120 as well as for the NCAM120 -specific $3^{\prime}$-noncoding region. Exons 16,17 , and 19 characterize both NCAM-140 and -180, whereas exon 18 codes for an additional cytoplasmic insert unique to NCAM-180 $(9-12)$

Received September 1, 1992.

Address all correspondence and requests for reprints to: Dr. Georgia Lahr, Abteilung Anatomie und Zellbiologie, Universität Ulm, AlbertEinstein-Allee 11, Postfach 4066, D 7900 Ulm, Germany.

* This work was supported by Deutsche Krebshilfe.
Recently, additional exons in the NCAM gene have been discovered in the NCAM CDNA. A 108-basepair (bp) insert, termed MSD1 (muscle-specific domain 1), located between exons 12 and 13 (splice site a) was found in a cDNA clone derived from human skeletal muscle (13) and was shown to be composed of three small exons of 15,48 , and $42 \mathrm{bp}$ and a $3^{\prime}$-AAG triplett adjacent to exon $13(14)$. These alternative exons can be used in various combinations (e.g. ex12-ex13, ex12- $\mathrm{a}_{15}-\mathrm{ex} 13$, and ex12-a $\mathrm{a}_{15}-\mathrm{a}_{48}-\mathrm{a}_{42}-\mathrm{ex} 13$ ); the resulting NCAM transcripts may contain, in addition, the AAG trinucleotide $(6,15-17)$. NCAM messengers containing these alternative or extra exons in splice site a are not restricted to skeletal muscle and have also been identified in heart (15, 18 ) and brain tissue $(6,17)$. Alternative splicing has been observerd at the exon $7 / 8$ splice junction of NCAM. At this site, a 30-bp extra sequence, termed variable alternatively spliced exon (VASE) in the rat or $\pi$ in the mouse $(6,19)$, was found. Its translation product changes the structure of the fourth immunoglobulin (Ig)-like domain (20). If all different combinations identified so far were translated, up to 192 different NCAM proteins could be generated (17). The function of most of these variants is unknown. However, one exactly defined NCAM species, namely NCAM-140-containing VASE, has recently been found to down-regulate neurite outgrowth (20).

NCAMs can also be posttranslationally modified by such mechanisms as sulfation, phosphorylation, myristinylation, and sialylation. Modulation of adhesion arises from differences in the lengths of homopolymers of $\alpha-(2,8)$-linkedneuraminic acid units ( polysialic acid or PSA) $(21,22)$ prob- 
ably linked to the fifth Ig-like domain of $\operatorname{NCAM}(23,24)$. PSA linked to NCAM appears to decrease cell adhesion, but enhances neurite outgrowth $(22,25,26)$. This indicates that VASE (see above) and PSA modulate NCAM functions in opposite directions.

Certain common properties of neurons and endocrine cells led to the investigation of NCAM expression in endocrine tissues and endocrine tumors. For example, the presence of NCAM has been demonstrated in chromaffin cells of the adrenal medulla $(27,28)$, islet of Langerhans endocrine cells, and the hypophysis $(27,29)$. NCAM-140 is the major isoform expressed in the rat adrenal gland, adenohypophysis, and pancreatic islets, but NCAM-180 is predominant in the neurohypophysis $(27,29)$. Also, the PC12 cell line, derived from a rat adrenal medullary pheochromocytoma, predominantly expresses NCAM-140 $(27,29)$ in addition to NCAM-180, which is increased by treatment with NGF (30). This isoform has been noted in rat insulinoma cells (RINA2) in addition to NCAM-140 (27). Because of the fuctional implications associated with modifications of the extracellular portion of NCAMs, we studied the presence of PSA linked to NCAM and the exon composition of NCAM isoforms expressed by endocrine tissues and derived tumors.

\section{Materials and Methods}

\section{Animals}

Adult 3- to 5-month-old female rats (Sprague-Dawley) were purchased from Charles River (Sulzfeld, Germany) and housed in our vivarium under standard conditions, with free access to food and water. Animals were killed by decapitation under deep $\mathrm{CO}_{2}$ anesthesia, and tissues were immediately removed and processed, as described below.

\section{Cell cultures}

Cell cultures of PC12 and RINA2 were grown under standard conditions in 60 -mm plastic dishes (Greiner, Nurtingen, Germany). In brief,

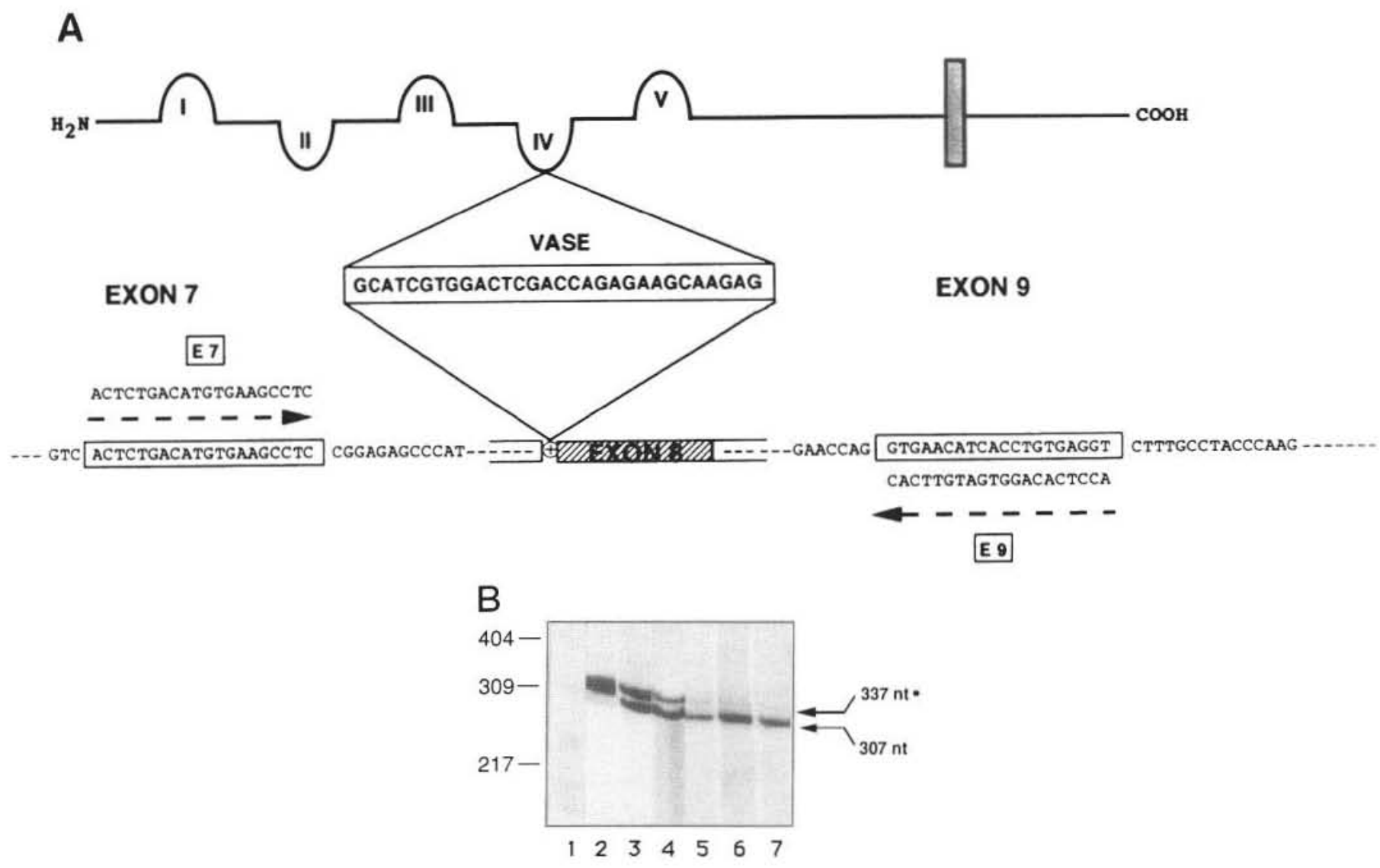

FiG. 1. VASE expression in endocrine tissues and tumor cells. A, Localization of VASE within NCAM-140. The extracellular part of NCAM contains five Ig-like domains (top). The cell membrane is indicated by the dark box, followed by the C-terminal cytoplasmic part of NCAM. The position of VASE between exons 7 and 9, which encode the fourth Ig-like domain, is shown. Part of the rat cDNA sequence of exons 7 and 9 is given. Oligonucleotide E7 5' -ACTCTGACATGTGAAGCCTC-3' is identical to the sense orientation, while oligonucleotide E9 5'-GTGAACATCACCTGTGAGGT $-3^{\prime}$ is antisense to the rat NCAM mRNA (19). B, NCAM mRNA with extra exon VASE is present in pituitary, adrenals, and endocrine tumor cells. RNA samples and and cDNAs were prepared from the indicated tissues and endocrine tumor cells, and PCRs were performed (see Materials and Methods). The radioactively labeled PCR reaction products were separated on $7.5 \%$ nondenaturing polyacrylamide gels. The products of 307 bases (without VASE) and 337 bases (with VASE; asterisk) are indicated. The experiment was repeated four times with similar results. $5^{\prime}{ }^{32} \mathrm{P}$-labeled size marker pBR322 digested with Hpall was applied to lane 1. Lane 2, Cerebellum; lane 3, pituitary; lane 4, adrenal; lane 5, PC12; lane 6, $\mathrm{GH}_{3}$; lane 7, RINA2. The PCR products of the adrenal applied to lane 4 had to be exposed twice as long to see the bands. NCAM RNA with VASE is abundant in the cerebellum, whereas NCAM mRNA without VASE prevails in adrenals and the the tumor cell lines examined. Equal amounts of both NCAM mRNA species exist in the pituitary. 


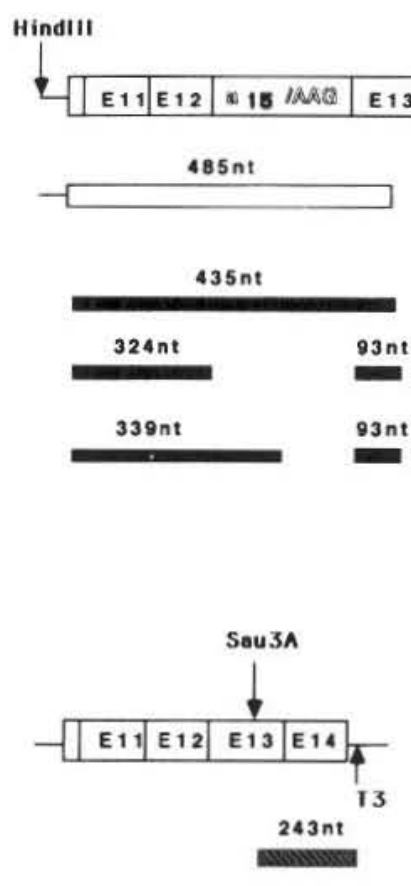

CDNA DW22

cDNA probe

protected

fragments

cDNA pM1.3

\section{CRNA probe}

FIG. 2. Scheme of the single stranded $c D N A$ and $c R N A$ probes used for $\mathrm{S} 1$ nuclease protection assays and ISH. The cDNA probe $(485 \mathrm{nt})$ synthesized from the mouse cDNA clone DW22 covers parts of exons 10, exons 11 and 12 totally, and parts of exon 13 and contains extra exon $\mathrm{a}_{15} / \mathrm{AAG}$. The 435-nt fragment protected from $\mathrm{S} 1$ nuclease hydrolysis indicates the presence of $a_{15} /+-A A G$. The protected fragments of 324 and $93 \mathrm{nt}$ indicate its absence. The protected band with the size of $339 \mathrm{nt}$ corresponds to NCAM mRNAs containing $\mathrm{a}_{15}$ and another extra exon (e.g. $\mathrm{a}_{48}$ and/or $\mathrm{a}_{42}$ ). The cRNA probe $(243 \mathrm{nt})$ synthesized from cDNA pM1.3, which was used for ISH, is shown at the bottom. Restriction sites are indicated by arrows; the transcription start site is indicated by the T3 promoter. The lines correspond to vector sequences.

PC12 cells were grown in Dulbecco's Modified Eagle's Medium (Biochrom Beteiligungs $\mathrm{GmbH}$, Berlin, Germany), and RINA2 cells were grown in RPMI-1640 medium (Biochrom Beteiligungs $\mathrm{GmbH}$, Berlin, Germany). $\mathrm{GH}_{3}$ cell cultures were grown under serum-free conditions in Dulbecco's Modified Eagle's Medium (Biochrom Beteiligungs $\mathrm{GmbH}$, Berlin, Germany) and Ham's nutrient mixture F-12 (Sigma, Deisenhofen, Germany) and, in addition, supplemented with insulin, transferrin, sodium selenite (Sigma), $10 \mathrm{nM} \mathrm{T}_{3}, 15 \mathrm{~mm}$ HEPES, $0.5 \mathrm{mg} / \mathrm{ml} \mathrm{BSA}$, and $50 \mu \mathrm{M}$ ethanolamine (Sigma). The $\mathrm{GH}_{3}$ cell line (31) was kindly provided by V. Hollt (Munich, Germany), the PC12 cell line (32) was supplied by $\mathrm{H}$. Thoenen (Munich, Germany), and the RINA2 cell line was provided by H. P. T. Ammon (Tubingen, Germany). The cells were collected and washed twice in PBS, and the cell pellets were stored until needed at $-20 \mathrm{C}$.

Isolation of cellular RNA, production of $c D N A$ as template, and amplification by polymerase chain reaction (PCR)

Total RNA was isolated by a modified guanidinium thiocyanate- $\mathrm{CsCl}$ method (33) from rat cerebelli, adrenals and isolated adrenal cortex, pituitaries, and cell cultures of PC12, RINA2, and $\mathrm{GH}_{3}$ cells. Total RNA was used as template for specific NCAM first strand CDNA synthesis, using the antisense 20-base oligonucleotide named E9 complementary to rat NCAM mRNA 5'-GTGAACATCACCTGTGAGGT-3'. This oligonucleotide hybridizes in the middle of exon 9 and contains 20 bases complementary to rat NCAM mRNA [bases 1505-1524 (34); see Fig. 1A]. This oligonucleotide is alsu complementary to mouse NCAM CDNA (12). Cellular RNA $(0.5 \mu \mathrm{g})$ was used in the first strand cDNA synthesis reaction. The cDNA synthesis was carried out for $25 \mathrm{~min}$ at $37 \mathrm{C}$ in the same reaction mix as that used for PCR amplification (see below) with
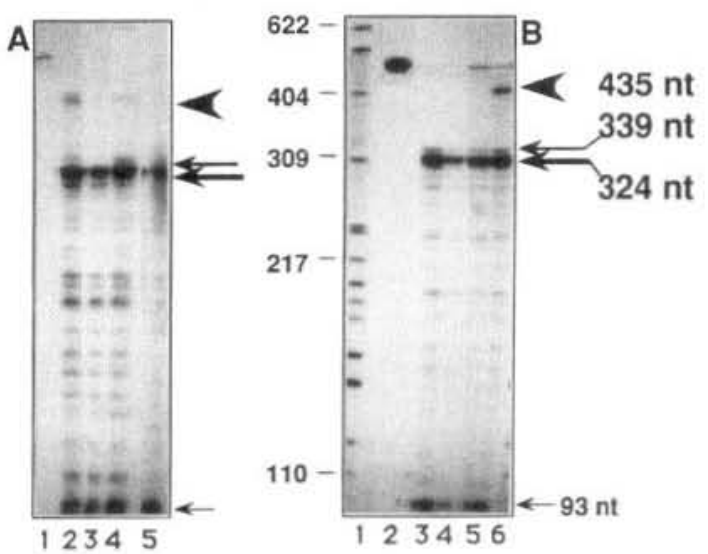

FIG. 3. S1 nuclease protection analysis of extracted mRNA of rat tissues and endocrine tumor cells. For S1 nuclease protection analysis of NCAM mRNAs, the probe DW22 (485 nt; see Fig. 2) was used. NCAM mRNA with extra exon $\mathrm{a}_{15} /+-\mathrm{AAG}$ is only present in pituitary and cerebellum, which was used as a control in A and B, as indicated by the protected band of $435 \mathrm{nt}$ (arrowhead). NCAM mRNAs of adrenals and the tumor cells examined do not contain this extra exon as a single insertion between constitutive exons 12 and 13 . The main bands of 324 and $93 \mathrm{nt}$ indicate that all endocrine tissues and tumor cells contain NCAM mRNA with no extra exon inserted. The band of $339 \mathrm{nt}$ indicates the insertion of exon $\mathrm{a}_{15}$, probably followed by other extra exons, such as $a_{48}$ and $a_{42}$ with or without the trinucleotide AAG. The 485-nt band in lane 2 represents undigested probe containing flanking vector sequences. A: Lane 1, Probe DW22 (485 nt; see Fig. 2); lane 2, cerebellum; lane 3 , adrenal; lane 4, pituitary; lane 5, adrenal cortex. B: Lane 1, Size marker; lane 2, probe DW22 (485 nt); lane 3, $\mathrm{PC} 12$; lane 4, $\mathrm{GH}_{3}$; lane 5, RINA2; lane 6, cerebellum. As a size marker (lane 1 in B), HpaII-digested pBR322-DNA labeled at the $5^{\prime}$-end with $\left[\gamma-{ }^{32} \mathrm{P}\right] \mathrm{ATP}$ was used.

$1 \mathrm{U}$ AMV reverse transcriptase (Angewandte Gentechnologie Systeme, Heidelberg, Germany).

Subsequently, the whole reaction mix was used directly as a template for the amplification by PCR. The antisense oligonucleotide E9 (see above) and the sense oligonucleotide E7 5'-ACTCTGACATGTGAAGCCTC-3' were used as primers for PCR amplification. Oligonucleotide $E 7$ has the same sequence as the protein-coding strand of the rat CDNA [bases 1187-1206 (34); see Fig. 1A]. PCR amplification (35) was performed immediately after inactivation of reverse transcriptase ( $95 \mathrm{C}$ for $1 \mathrm{~min}$ ) in a $50-\mu \mathrm{l}$ reaction mix containing $10 \mathrm{~mm}$ Tris- $\mathrm{HCl}$ ( $\mathrm{pH}$ 8.4); $50 \mathrm{~mm} \mathrm{KCl} ; 2.5 \mathrm{~mm} \mathrm{MgCl} 2 ; 0.1 \mathrm{~mm}$ dithiothreitol; $0.02 \%$ gelatin (Sigma); 0.2 mM deoxy-ATP (dATP), dTTP, and dGTP; $0.1 \mathrm{mM} \mathrm{dCTP;} 5$ $\mu \mathrm{Ci}\left[\alpha-{ }^{32} \mathrm{P}\right] \mathrm{dCTP}$ (Amersham, Dreieich, Germany); $50 \mathrm{pmol}$ of each primer; and $1 \mathrm{U}$ Taq DNA polymerase (Boehringer, Mannheim, Germany). The probes were subjected to 3030 -sec cycles at $93 \mathrm{C}, 1 \mathrm{~min}$ at $62 \mathrm{C}$, and $2 \mathrm{~min}$ at $72 \mathrm{C}$. Two-microliter aliquots were directly loaded onto nondenaturing $7.5 \%$ polyacrylamide gels in $1 \times$ TBE buffer (TrisBorate-EDTA; $50 \mathrm{~mm}$ Tris base, $50 \mathrm{~mm}$ boric acid, and $1 \mathrm{~mm}$ EDTA). After running, the gels were dried, and the PCR products were visualized by applying the gels to $x$-ray films for exposure at $-70 \mathrm{C}$ for 1 day using intensifying screens.

The specificity of PCR products was analyzed by "cold" PCR amplification. Fifteen-microliter aliquots of the PCR reaction were separated on $2 \%$ Agarose gels (Serva, Heidelberg, Germany) in TBE buffer together with a negative (no RNA) and a positive control (NCAM CDNA clone N1) (6). After the run was completed, the gels were subjected to Southern transfer analysis (36) using Biodyne A membranes $(0.2 \mu \mathrm{m}$; Pall Filtrationstechnik, Dreieich, Germany). The blots were first hybridized with an isotopically labeled cRNA probe derived from the NCAM cDNA clone N1 (6), which contains extra exon VASE (see Fig. 2A); as a further control we applied hybridization with a nonoverlapping labeled CDNA probe (pM1.3) (37). PCR products were visualized by applying the Southern blots to $x$-ray films for exposure at $-70 \mathrm{C}$ for 1 or 3 days using intensifying screens. 
Fig. 4. Detection of NCAM mRNA by ISH of sections of the pituitary. A, NCAM mRNA could be localized predominantly in the mixed cell population of the adenohypophysis (ah) and in the pars intermedia (pi). Few grains were observed over the neurohypophysis (nh). B, Control. Sections were prehybridized overnight at $50 \mathrm{C}$ with cold-transcribed antisense cRNA probe. The sections were then hybridized with the labeled cRNA probe overnight at 50 C. Bars equal $20 \mu \mathrm{m}$.

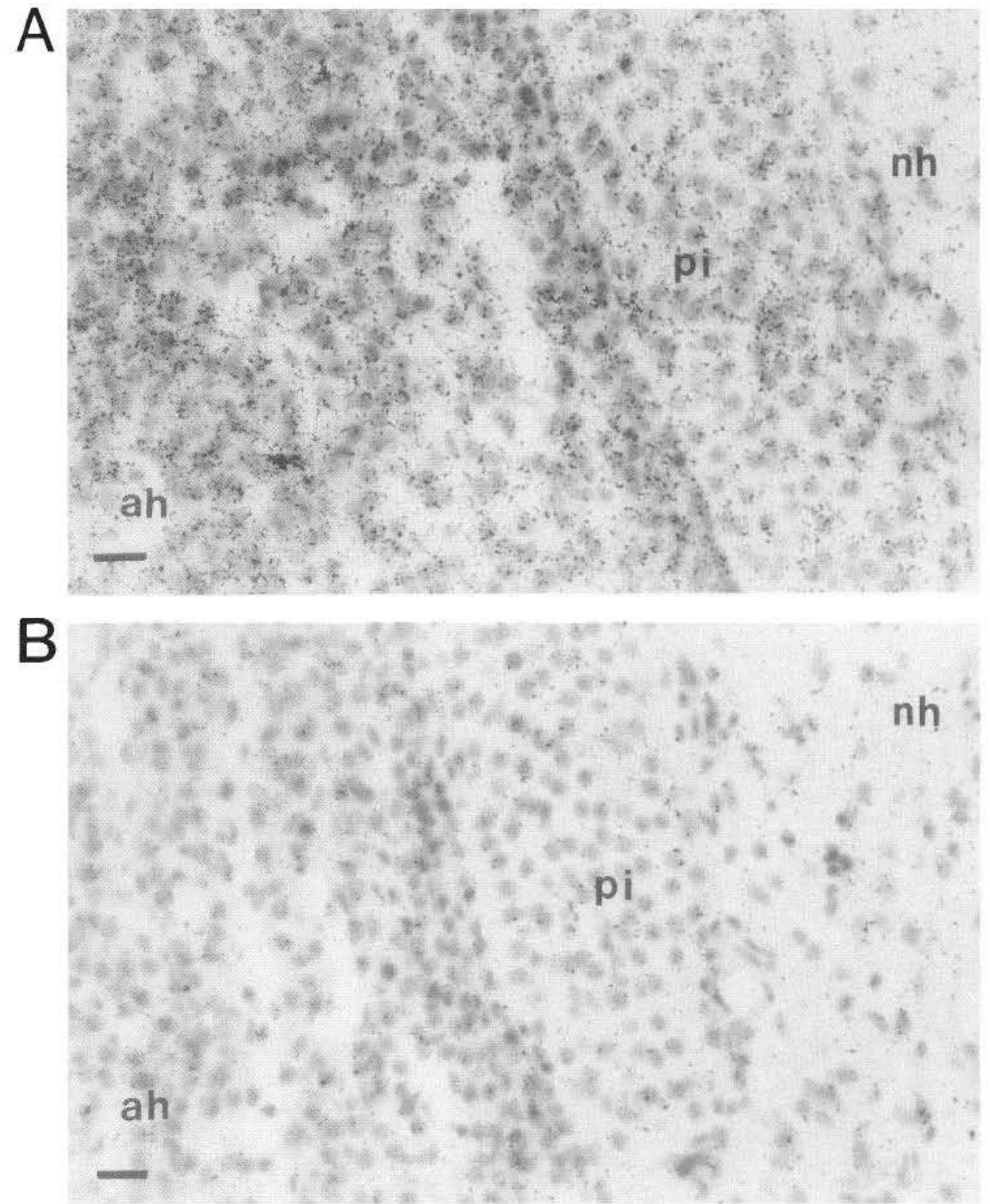

The accuracy of amplification was also tested by restriction analysis with the enzyme TaqI, which cuts within the extra exon VASE, thus generating a fragment of 94 nucleotides (nt). Therefore, we included in the PCR isotopically labeled substrate, separated the PCR products on nondenaturing polyacrylamide gels, recovered the bands, and subjected them to restriction analysis with the restriction enzyme TaqI. The resulting isotopically labeled restriction fragments were visualized after separation on nondenaturing polyacrylamide gels by applying the dried gels to $x$-ray films.

\section{cDNA and cRNA probes used for S1 nuclease protection assays and in situ hybridization histochemistry (ISH)}

The mouse NCAM cDNA used for cDNA probe sythesis in this study has been previously characterized $(6,12)$.

DW22. This clone is a M13 mp19 EcoRI cDNA clone isolated from a cDNA library of total brain (without cerebellum) from neonatal mice. DW22 includes exons $10-15$ (position $1635-2601)(6,12)$. The probe derived thereof covers parts of exon 10 , exons 11 and 12 totally, and parts of exon 13. It also contains the extra exon $a_{15} / A A G$ at the exon
12/13 splice junction (see Fig. 2A).

Uniformly labeled single stranded cDNA probe was prepared, as previously described (38), by use of oligonucleotide 738 (5'-CCAGATAGTGTCTGATG-3'), which hybridizes to nt position 2054-2070 of exon 13 (12). The labeled primer-extended NCAM clone DW22 was digested with HindIII, yielding two fragments. These fragments were separated on $5 \%$ polyacrylamide gels (containing $8.3 \mathrm{M}$ urea), and the 485 -nt fragment was isolated, as previously described (38). The purified fragment yielded was used for the S1 nuclease protection assay. The position and orientation of this fragment are given in Fig. 2A.

As a template for cRNA synthesis, we used the cDNA clone pM1.3 in pGEM-1 vector (Promega Biotec, Madison, WI), a generous gift from Dr. C. Goridis (Marseille, France) (37).

Synthesis of ${ }^{35} \mathrm{~S}$-labeled cRNA (SA, $8 \times 10^{8} \mathrm{cpm} / \mu \mathrm{g}$ ) for ISH was carried out according to the T3 polymerase protocol of Promega Biotec, using $107 \mu \mathrm{Ci}\left[\alpha-{ }^{35} \mathrm{~S}\right] \mathrm{CTP}$ (SA, 37 Tera-Bequerel/mM) and NCAM CDNA clone pM1.3 cut with Sau $3 \mathrm{~A}$. The resulting cRNA probe contained 221 nt within exons 13-14 (position 2028-2249) and $22 \mathrm{nt}$ of vector sequences (see Fig. 2A). We used this shorter cRNA probe of $243 \mathrm{nt}$ to facilitate tissue penetration.

As a probe for the analysis of the blotted PCR products, we used as 
A

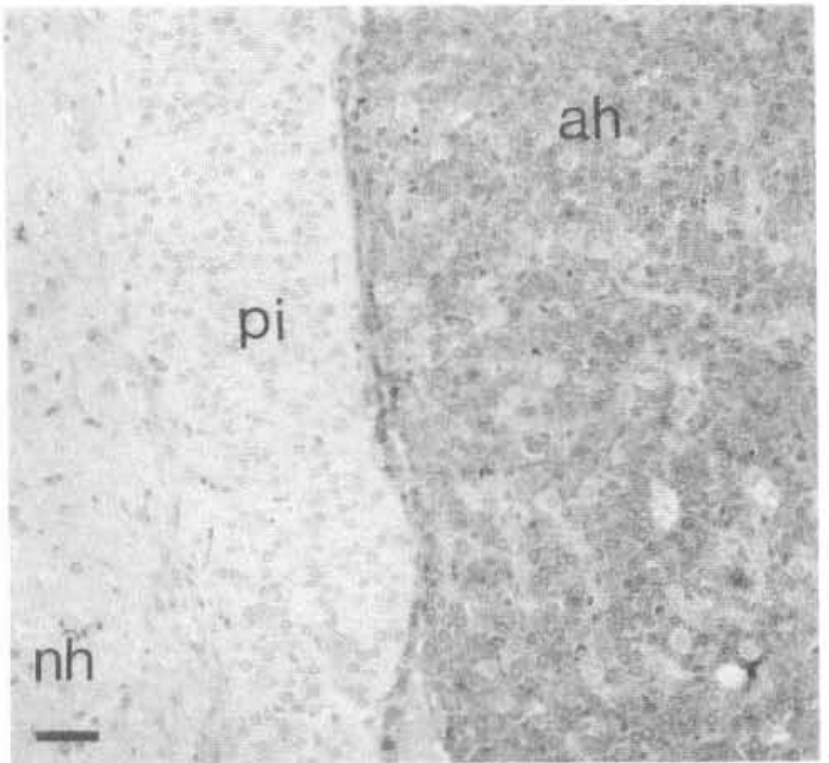

$\mathrm{B}$

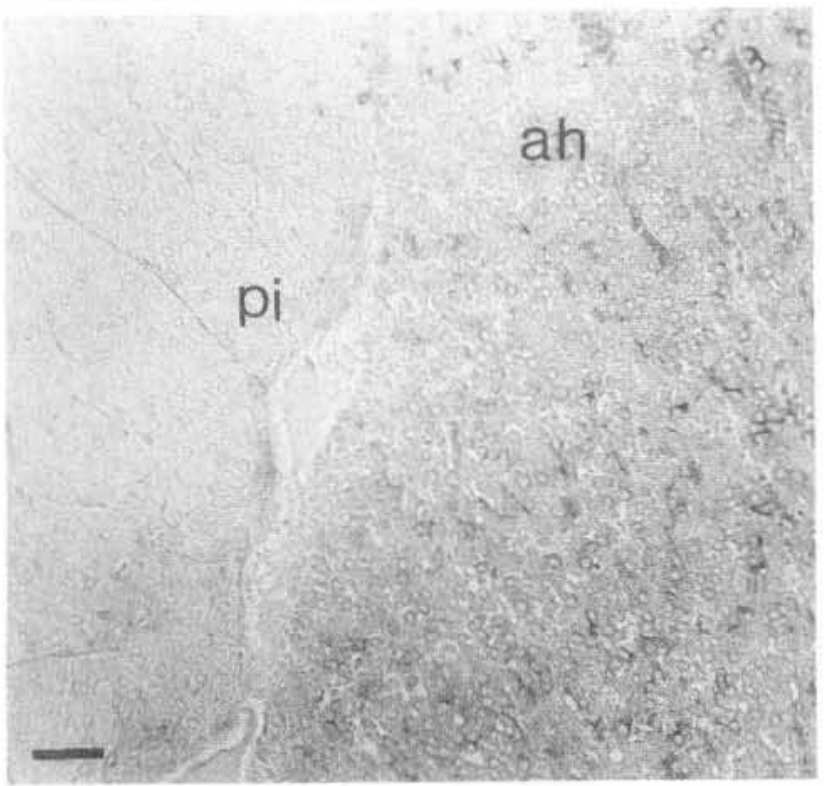

Fig. 5. Detection of NCAM and PSA linked to NCAM by immunocytochemistry in sections of the pituitary. Polysialylated NCAM as well as NCAM could be localized predominantly in the mixed cell population of the anterior lobe and the pars intermedia. ah, Adenohypophysis; pi, pars intermedia; nh, neurohypophysis. A, Monoclonal MoAB735 PSA antibody; B, polyclonal antiserum against the Ig-like domains of NCAM. The immunostaining is confined to the cell contact zones (arrows). The bar equals $40 \mu \mathrm{m}$.

a template for cRNA synthesis the cDNA clone N1 (6) in the Bluescript M13(+)-KS vector (Stratagene, La Jolla, CA). Synthesis of $\alpha{ }^{32} \mathrm{P}$-labeled cRNA (SA, $1.1 \times 10^{8} \mathrm{cpm} / \mu \mathrm{g}$ ) for hybridization was carried out according to the T7 polymerase protocol (Promega Biotec), using $20 \mu \mathrm{Ci}\left[\alpha-{ }^{32} \mathrm{P}\right]$ UTP (SA, 15 Tera-Bequerel/mm) as well as NCAM cDNA clone N1 cut with Hincll. The resulting N1 cRNA probe used for Southern blot analysis contained 2018 nt within exons 2-15, including extra exon VASE and $60 \mathrm{nt}$ of vector sequences.

\section{S1 nuclease protection assay (S1-NPA)}

S1-NPA was carried out as described previously (39). Briefly, $20 \mu \mathrm{g}$ total RNA (determined photometrically) were hybridized with an excess of ${ }^{32} \mathrm{P}$-labeled cDNA probe $\left(5 \times 10^{4} \mathrm{cpm} ; \mathrm{SA}, 1 \times 10^{8} \mathrm{cpm} / \mu \mathrm{g}\right)$ in $75 \%$ formamide, $400 \mathrm{~mm} \mathrm{NaCl}, 1 \mathrm{~mm}$ EDTA, and $20 \mathrm{~mm}$ Tris- $\mathrm{HCl}$ (pH 7.4) for $16 \mathrm{~h}$ at $58 \mathrm{C}$. Hybridization was terminated by digestion with $680 \mathrm{U}$ S1 nuclease (Angewandte Gentechnologie Systeme, Heidelberg, Germany) for $2 \mathrm{~h}$ at $37 \mathrm{C}$. After phenol extraction and ethanol precipitation, samples were separated electrophoretically on $0.3-\mathrm{mm}$ thick $5 \%$ poly. acrylamide gels $(8.3 \mathrm{M}$ urea). Gels were dried and applied to $\mathrm{x}$-ray film for exposure at $-70 \mathrm{C}$ for 5 days using intensifying screens.

\section{ISH}

Adrenals of female rats were immersed in Bouin's fixative for $12 \mathrm{~h}$ and processed for routine paraffin embedment. Serial sections $(5 \mu \mathrm{m})$ were cut and mounted on 3-aminopropyltriethoxysilane-coated (Sigma) glass slides. Sections were deparaffinized, using a sequence of xylene, ethanol, chloroform, and ethanol, and subsequently air dried. Pituitaries of female rats were frozen in liquid nitrogen, and kryostat sections (7 $\mu \mathrm{m})$ were mounted on 3-aminopropyltriethoxysilane-coated glass slides and fixed with $4 \%$ paraformaldehyde in $0.01 \mathrm{M} \mathrm{PBS} \mathrm{(} \mathrm{pH} 7.3$ ) for $30 \mathrm{~min}$ at room temperature.

The sections were prehybridized at $50 \mathrm{C}$ with hybridization solution for $3 \mathrm{~h}$, as described previously (39). Subsequently, they were hybridized at $50 \mathrm{C}$ overnight with $5 \mathrm{ng}$ labeled cRNA probe $\left(\mathrm{SA}, 8 \times 10^{8} \mathrm{cpm} / \mu \mathrm{g}\right)$ in $150 \mu \mathrm{l}$ hybridization solution in a humified chamber. Controls consisted of sections either pretreated with $100 \mu \mathrm{g} / \mathrm{ml}$ RNase-A (Boehringer) at $37 \mathrm{C}$ for $30 \mathrm{~min}$ or prehybridized overnight at $50 \mathrm{C}$ with coldtranscribed antisense CRNA probe before hybridization with the labeled CRNA probe. After hybridization, sections were washed as described. To reduce background, sections were treated for $30 \mathrm{~min}$ at $37 \mathrm{C}$ in a buffer containing $100 \mu \mathrm{g} / \mathrm{ml}$ RNase-A. After additional washes, slides were rinsed in ascending alcohol solutions, air dried, and dipped in Ilford (Cheshire, England) $\mathrm{K} 2$ emulsion diluted $1: 1$ with $\mathrm{H}_{2} \mathrm{O}$. They were exposed for 3-6 weeks at 4 C and developed with Kodak D19 (Eastman Kodak, Rochester, NY) at $16 \mathrm{C}$ for $4 \mathrm{~min}$. The sections were counterstained either with hemalaun (Mayer) and eosin or with giemsa solution and photographed with a Zeiss Axioplan photomicroscope (Oberkochen, Germany).

\section{Immunocytochemistry}

Immunocytochemical procedures were described previously in detail $(39,40)$. In brief, $5-\mu \mathrm{m}$ sections of Bouin's-fixed and embedded tissues were deparaffinized and permeabilized for $5 \mathrm{~min}$ with Triton X-100 in PBS ( $10 \mathrm{~mm}$ phosphate and $150 \mathrm{~mm} \mathrm{NaCl}, \mathrm{pH} 7.3)$, followed by a 5 min incubation with $0.03 \% \mathrm{H}_{2} \mathrm{O}_{2}$ in $10 \%$ methanol in PBS to quench endogenous peroxidase activity. In addition, cultured RINA2, $\mathrm{GH}_{3}$, and $\mathrm{PC} 12$ cells grown in plastic culture dishes (Costar, Cambridge, MA) were fixed with $4 \%$ paraformaldehyde in $0.01 \mathrm{M}$ PBS (pH 7.3). Sections or cells were used for detection of the PSA epitope uniquely linked to NCAM in mammals, employing the monoclonal antibody MoAB 735 (generous gift from Dr. D. Bitter-Suermann, Hannover, Germany) (41). The MoAB antibody is directed against homopolymeric $\alpha-(2,8)-\mathrm{N}$-acetylneuraminic acid. Sections and fixed cells were incubated with MoAB (1:200 to 1:1000) overnight. For detection with the avidin-biotin-peroxidase complex method (42), a biotinylated horse antimouse IgG antiserum (1:500; Camon, Wiesbaden, Germany), and a commercial avidinbiotin-peroxidase kit (Vectastain, Camon, Wiesbaden, Germany) were used with $3^{\prime}, 3^{\prime}$-diaminobenzidin tetrahydrochloride dihydrate as chromogen (Aldrich, Milwaukee, WI). Alternatively, avidin-labeled fluorescein isothiocyanate (Fluorescein Avidin D, Camon, Wiesbaden, Germany) was used (1:250 to $1: 1000$ in $15 \mathrm{~mm}$ HEPES, pH 7.2).

For detection of NCAM in cultured tumor cells, we also used a polyclonal rabbit NCAM antiserum (43); directed against the N-terminal 11-amino acid sequence of mouse NCAM (LQVDIVPSQGE), which was a generous gift from Dr. G. Rougon (Marseille, France). Incubations with this antibody (1:1000) were carried out overnight.

For detection of NCAM in paraffin sections of rat pituitary and adrenal gland, we also used IgG-like domains of the mouse NCAM (corresponds to position 212-1635 of cDNA) (12). Incubations with this antibody $(1: 500)$ were performed overnight. Controls consisted of ommission of the first antibody and incubation with rabbit serum or mouse IgG (1:500 to $1: 1000)$. Sections were examined with a Zeiss Axioplan microscope (Oberkochen, Germany). 
FIG. 6. Detection of NCAM and PSA linked to NCAM by ISH (B and D) and immunocytochemistry (A and C) of sections of the adrenal gland. NCAM mRNA and PSA linked to NCAM are present in the adrenal gland. NCAM mRNA and polysialylated NCAM (by use of the monoclonal MoAB735 PSA antibody) were detected predominantly in the cortical region of adrenals (I, zona glomerulosa; II, zona fasciculata; III, zona reticularis). Less NCAM was observed in the medulla (IV). The bar equals $40 \mu \mathrm{m}$.
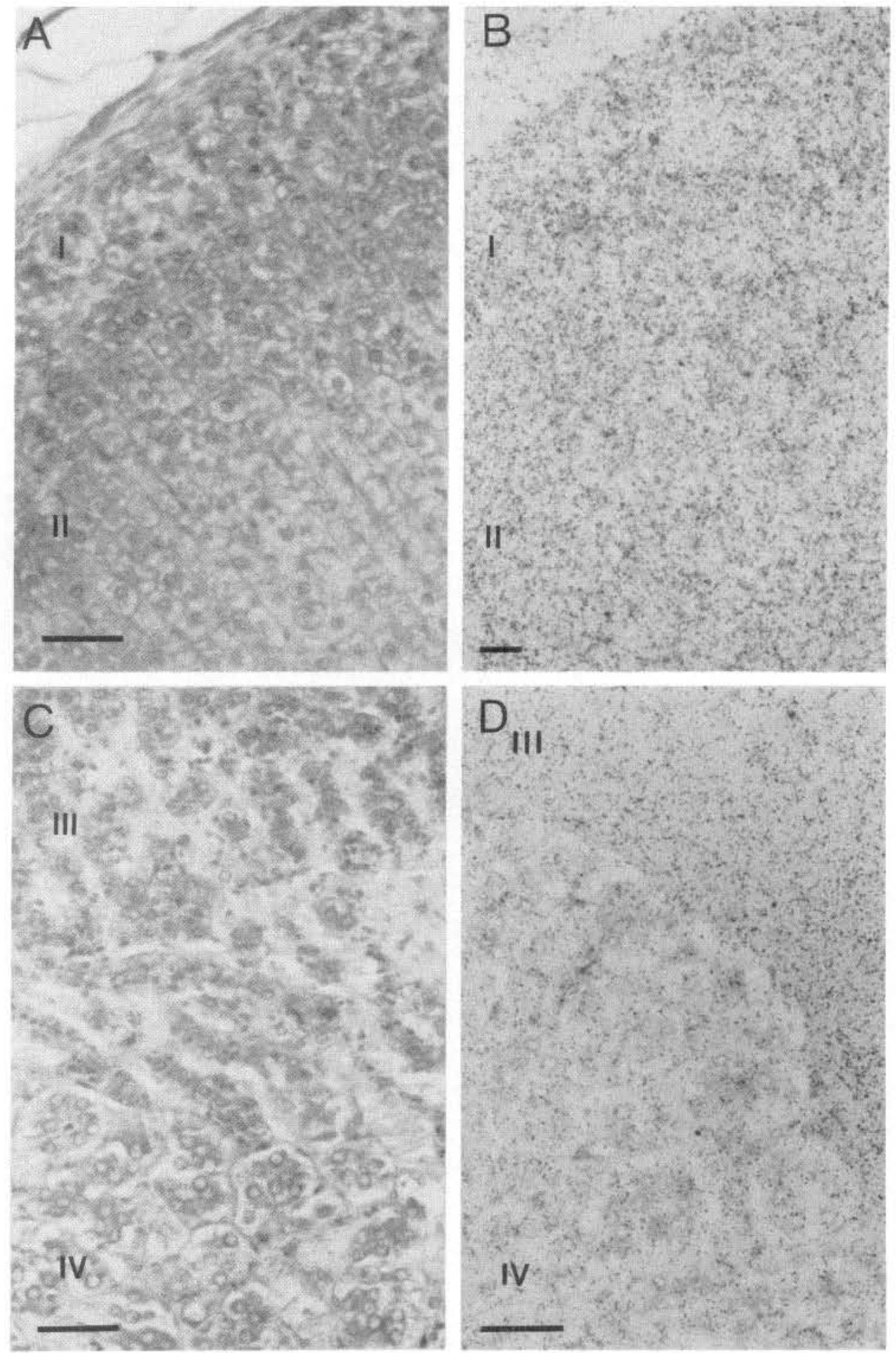

\section{Results}

Structure of endocrine NCAM mRNAs

Alternatively spliced extra exon VASE is present in neuroendocrine tissues and tumor cell lines of the rat. The PCR technique was chosen to determine the presence of the alternatively spliced extra exon VASE. Oligonucleotide primers down- and upstream from the exon $7 / 8$ splice junction were used (Fig. 1A). After cDNA synthesis and PCR amplification, we detected in rat pituitaries, adrenals, and the different endocrine tumor cell lines two fragments of 307 and $337 \mathrm{bp}$, representing transcripts with and without VASE (Fig. 1B). In the pituitary, equal amounts of VASE and non-VASE mRNAs were present, whereas in the cerebellum, VASE was 


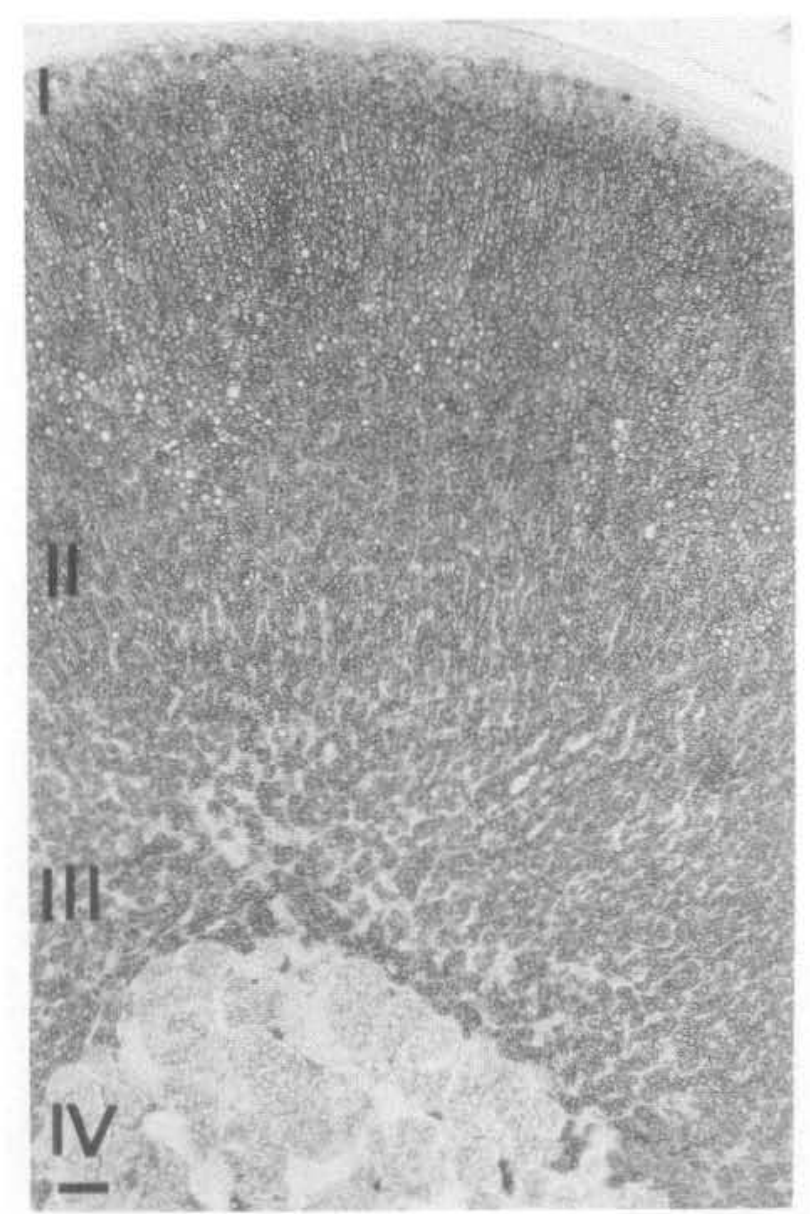

FIG. 7. Detection of NCAM by immunocytochemistry of a section of the adrenal gland. As demonstrated for NCAM-PSA in Fig. 6, A and C, NCAM was detected predominantly in the cortical region of adrenals in zona reticularis (III). Less NCAM was observed in the medulla (IV) with the polyclonal antiserum directed agaist the Ig-like domains of NCAM. The bar equals $40 \mu \mathrm{m}$.

contained in most NCAM mRNAs. In contrast, adrenals contained smaller amounts of NCAM with VASE, whereas the tumor cell lines examined expressed VASE-containing transcripts to a minor extent.

The presence of VASE in the PCR products was verified by Southern blot, followed by hybridization to a labeled cRNA probe derived from cDNA clone N1 containing extra exon VASE (6) (data not shown). A nonoverlapping labeled cDNA probe (pM1.3) (37) served as a control. In addition, we carried out S1-NPA (not shown) using a mouse brain cDNA probe (cDNA clone N1) (6) covering exons 4-10, including VASE. Within the resolution of S1-NPA, we found 1) identical exons $4-10$ in endocrine and neural NCAMs, and 2) RNAs with and without VASE in rat pituitaries, adrenals, and the different endocrine tumor cell lines analyzed.

The accuracy of amplification was also tested by restriction analysis with the enzyme TaqI, which cuts within the extra exon VASE. The 337-nt PCR fragment (containing VASE) is cleaved within VASE, thus generating an additional fragment of $94 \mathrm{nt}$.
Alternatively spliced extra exons at splice site a. A cDNA probe (see experimental procedures and Fig. 2A) spanning parts of exon 10, exons 11 and 12 totally, and parts of exon 13 , including the extra exon $\mathrm{a}_{15} / \mathrm{AAG}$ at the exon $12 / 13$ junction, was used in S1-NPAs to examine extracted cellular RNAs of the different endocrine rat tissues and tumor cells (Fig. 3). A protected band of $435 \mathrm{nt}$ was found in total RNA of rat cerebellum (used as control tissue) and pituitary, but not in both parts of the adrenals. This indicates that a diversity of NCAM forms exists in the pituitary with the structure ex12$a_{15} / A A G-e x 13$ or ex12-a $a_{15}-$ ex13. Two major bands of 324 and $93 \mathrm{nt}$ of protected probe DNA were observed in the hybridization samples with RNAs extracted from pituitaries, adrenals, and isolated adrenal cortex. This indicates the presence of NCAM mRNAs without alternative extra exons at splice site a (Fig. 3A). Within the resolution of S1-NPA, insulinoma (RINA2), pheochromocytoma (PC12), and the adenohypophysial tumor cell lines $\left(\mathrm{GH}_{3}\right)$ were devoid of the ex12- $a_{15} /$ with or without AAG-ex13 arrangement in NCAM mRNA. This was demonstrated by the presence of the two major bands of 324 and $93 \mathrm{nt}$ and the absence of a 435-nt band presenting full protection of the DNA probe (Fig. 3B). An additional band of approximately $339 \mathrm{nt}$ in all tissues and tumor cell lines examined might indicate the presence of exon $a_{15}$ followed by other alternatively spliced exons, such as $\mathrm{a}_{48}$ and $\mathrm{a}_{42}$, with or without an AAG triplett between the exons 12 and $13(14,17)$.

\section{ISH and immunocytochemistry}

In previous immunocytochemical studies $(27,40,44,45)$, it was shown that NCAM is confined to the surfaces of human and rat endocrine cells. We applied ISH and used an antibody directed against the PSA epitopes linked to NCAM as well as an antibody directed against the Ig-like domains present in all three main NCAM isoforms as well as an antibody recognizing the very $\mathrm{N}$-terminal part of NCAM to find out whether NCAM posttranslationally modified by sialic acid homopolymers is expressed in endocine tissues and tumor cells.

In the pituitary, the NCAM cRNA probe hybridized mainly to cells of the pars intermedia and the mixed cell population of the anterior lobe of the hypophysis, but few grains were associated with the neural lobe (Fig. 4A). The specificity of the hybridization is documented in Fig. $4 \mathrm{~B}$, in which prehybridization with cold transcribed antisense cRNA abolished the specific labeling (Fig. 4A). In the anterior lobe of the hypophysis, most of the endocrine cells were heavily labeled with the PSA antibody, but a small percentage of cells appeared to be unstained (Fig. 5A). The immunoreactivity of the cells of the intermediate lobe was low with both the PSA antibody and the polyclonal antiserum directed against the lg-like domains of NCAM (Fig. 5B). The latter antiserum confirmed the presence of NCAM, especially at the cell surface of adjacent endocrine cells in the anterior lobe (Fig. $5 B)$.

In the adrenals, NCAM mRNA and polysialylated NCAM were detected predominantly in the cortical region of the adrenals, i.e. the zona glomerulosa (I) and zona fasciculata 
FIG. 8. NCAM is present in the endocrine tumor cell lines $\mathrm{GH}_{3}$, RINA2, and $\mathrm{PC} 12$. The polyclonal antiserum was used to detect NCAM in RINA2 cells. Polysialylated NCAM was detected immunocytochemically using PSA antibodies. A, RINA2 and MoAB735, brightfield. B, RINA2 and polyclonal antiserum directed against the $\mathrm{N}$-terminus of NCAM, brightfield. C, $\mathrm{GH}_{3}$ and MoAB735, fluorescence. D, PC12 and MoAB735, brightfield. Bars equal $20 \mu \mathrm{m}$.
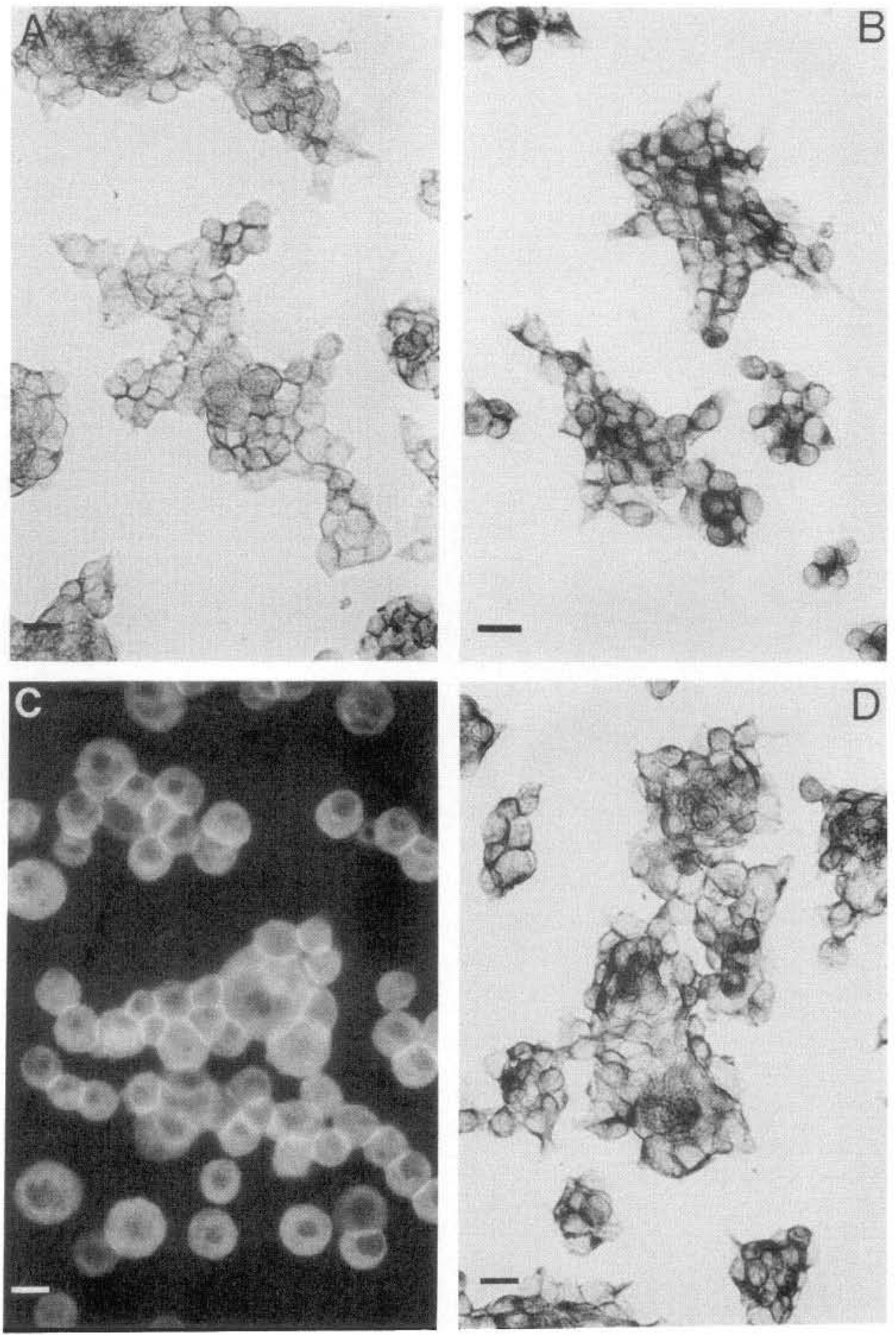

(II; Fig. 6). However, NCAM mRNA and polysialylated NCAM were also observed in the zona reticularis (III) and, to a lesser extent, in the adrenal medulla (IV; Fig. 6). A similar NCAM distribution was observed in the adrenal gland with the polyclonal antiserum directed against the Ig-like domains of NCAM (Fig. 7). Cell clusters with stronger immunoreactivity were prominent mainly in the adrenal medulla. The tumor cell lines PC12, $\mathrm{GH}_{3}$, and RINA2 also exhibited intense
NCAM and NCAM-PSA immunoreactivities, which were confined to cell surfaces and were particularly intense at contact sites between the cells (Fig. 8).

\section{Discussion}

Similarities in development and functional characteristics reveal a close relationship between endocrine cells and neu- 
rons. Thus, it is not surprising that these cells have a variety of cellular constituents in common, which can be used as markers. One of the molecules expressed by both cell types is $\operatorname{NCAM}(2,27,44,45)$. NCAMs are involved in cell-cell interactions and are believed to play a critical role in specifying cell patterning and movement during early embryogenesis, in particular during neurogenesis. NCAMs have also been implicated in morphogenetic events in later development $(13,46)$. In the present investigation, we analyzed the molecular structure of NCAM mRNA with respect to alternative splicing events as well as the distribution of posttranslationally modified NCAM in endocrine cells. We focused on recently detected alternative extra exons as well as PSA linked to NCAM, which have been recognized as functional modifications of $\operatorname{NCAM}(20,25,26,47)$.

The extracellular as well as intracellular parts of the NCAM molecules of endocrine cells can be modified in sequence by the molecular process of alternative splicing at the mRNA level, thus generating structurally related, but distinct, protein isoforms from a single gene. The NCAM-140 isoform prevails in endocrine cells $(27,29,44,45)$. In the coding region for extracellular domains of NCAM, there are two sites where alternative extra exons may be included in the mRNA as a consequence of an alternative splicing event: between exons 7 and 8 (termed VASE or $\pi$ ) and between exons 12 and 13 (termed the a-exons with or without the triplett AAG) $(6,15,17,48)$. We detected different degrees of exon VASE in all endocrine tissues and related tumors examined. In accordance with a previous report (48), we found that the adult adrenal gland expresses small amounts of NCAM mRNAs that contain VASE. In the rat pituitary, the amounts of VASE-containing mRNA vs. non-VASE mRNA are balanced, whereas in the cerebellum, VASEcontaining mRNAs appeared to be more abundant (see also Ref. 48). The tumor cell lines expressed less of the spliced VASE variant. Exon VASE would contribute 10 additional amino acids in the fourth Ig-like domain, and this exon could be present in mRNAs coding for all three major NCAM isoforms (15). The position of this insert of 10 amino acids within the fourth NCAM Ig-like loop is reminiscent of the position of amino acids that make up the hypervariable regions of the Ig polypeptides. Since similar sequence alterations affect the structure and function of Ig domains (49), this alternative exon could substantially alter the ability of NCAM to mediate adhesion during development (48). Indeed, a modification as a consequence of an alternative splicing event greatly affects the function of NCAM. It has recently been shown that alternative exon VASE downregulates the neurite outgrowth activity of NCAM-140 (20).

It has been demonstrated that the large intron of $\sim 20$ kilobases between exons 12 and 13 contains several small alternatively spliced exons $(6,14,18)$. We found that the 15 nucleotides of the extra sequences described previously (13), termed exon $\mathrm{a}_{15}$, with or without an additional AAG triplet (6) are also present in the pituitary, but not in other tissues or cells analyzed. NCAM mRNA populations in this tissue were composed mainly of the constituitve exons ex12-ex13, i.e. with no alternative exons in between. In addition, frag- ments of about 339 nt observed in S1-NPA indicate possible further modifications, such as alternative exons $\mathrm{a}_{42}$, or $\mathrm{a}_{48}$. In contrast to VASE (see above), the functional consequences of the insertion of alternative extra exons at the exon $12 / 13$ splice junction, such as $a_{15}$ or $a_{48}$ and $a_{42}$ with or without the AAG triplett in the coding region of the NCAM molecule of endocrine pituitary cells, remain to be investigated. However, the striking accumulation of three adjacent prolines in $a_{15}$ suggests that this short inserted segment may render the postulated hinge more flexible, change its angle (6), or modify the possible fibronectin type III-like region encoded by exon 12 (50).

At present, it is not known whether NCAMs containing the sequence encoded by $a_{15}$ with or without AAG and all other alternative exon combinations are restricted to a certain type of endocrine cells in the anterior lobe or are even expressed within one cell type to distinct cell surface areas. It is worth noting at this point that examples of the presence of certain NCAM isoforms confined to distinct surface areas of epithelial and neuronal cells have been recently observed. Powell et al. (51) demonstrated that the different isoforms of NCAM are indeed targeted to different surface areas, e.g. NCAM-140 and -180 only to the basolateral surface of epithelial cells. On the other hand, the posphatidyl anchor of NCAM-120 serves as a targeting signal for apical localization. Similarly, as was demonstrated in brain tissue, NCAM180 was concentrated at sites of cell contacts and at postsynaptic densities $(52,53)$.

One of the most striking features of NCAM is its degree of developmentally regulated polysialylation. Posttranslationally added PSA appears to affect the homophilic binding of NCAM by altering conformation, by simple charge repulsion or direct steric hinderence $(22,25)$. The amount of sialic acid decreases during development, suggesting that changes in the amount of sialic acid are used as a mechanism to modulate NCAM activity in vivo (47). The change from embryonic to adult forms of NCAM, which have less PSA (54), occurs at different rates in different brain regions. It is delayed in the mouse cerebellar mutant, known as staggerer mouse, again suggesting a regulatory role (47). Available evidence reveals a causal relationship between PSA expression and activity-dependent plasticity in the hypothalamoneurohypophyseal system (55) or during the establishment of intramuscular nerve branching (46).

The long polysialic acid units composed of $\alpha$-(2,8)-linked $N$-acetylneuraminic acid units are found exclusively on NCAM in vertebrates and are not associated with other proteins (55-57). Our observations indicate that PSA linked to NCAM is not expressed in all adenohypophyseal cells to the same extent. Low amounts of PSA linked to NCAM have been observed in the intermediate lobe, whereas, with a few exceptions, most cells of the anterior lobe were heavily stained. Most cells of the anterior lobe are acidophiles, which secrete PRL and/or GH depending on the input of hypothalamic factors and steroid hormones (58). Therfore, the presence of heavily sialylated NCAM in the anterior lobe could be related to the cell type and/or hormonal plasticity of the pituitary cells. 
Immunostaining suggested that PSA linked to NCAM is more frequent in the adrenal cortex than in the adrenal medulla. Within the cortex, the cells in the zona glomerulosa appeared to contain more of these surface components than the other parts. A similar distribution of NCAM has been noted by Poltorak (59). The functions of adrenal cortical cells are regulated by angiotensin-II and ACTH. Furthermore, the zona glomerulosa may be regarded as a regenerative zone of the adrenal cortex (60), and cells of the zona glomerulosa might lose NCAM immunoreactivity and PSA after migration to the zona fasciculata. Similar to the situation in the adenohypophysis, the occurence of PSA linked to NCAM may explain the capability of the adrenal cortex to respond to a variety of physiological stimuli. A further example of the presence of PSA linked to NCAM in a system of extensive remodeling controlled by hormones is the ovary (40). Clearly, the precise role played by PSA during remodeling remains to be investigated.

All endocrine tumor cell lines examined exhibited strong NCAM-PSA immunoreactivities at the cell surface. The staining was seen predominantly at the contact sites between $\mathrm{GH}_{3}$ (a clonal strain of rat pituitary tumor cells), PC12 (a rat pheochromocytoma), and RINA2 (a rat insulinoma) cell lines. On the other side, these cell lines also express a low sialylated NCAM isoform $(27,29)$. The combination of high sialylated as well as low sialylated NCAMs may indicate complex involvement of these different forms of NCAM in adhesion between the tumor cells.

In summary, the major findings of the present study are that NCAMs modified in several ways are present in the hypophysis and adrenals. Cells of the anterior lobe express more PSA linked to NCAM than those of the intermediate lobe. About half of the NCAM molecules present in the hypophysis appear to have an insert of $30 \mathrm{bp}$ (extra exon VASE) in the region coding for the Ig-like domain IV, and further modifications at the splice site a, coding for postulated hinge region, are also evident. In the adrenal, NCAM and PSA linked to NCAM are mainly confined to the adrenal cortex. In this tissue, NCAM containing VASE vs. NCAM without VASE is of low abundance, and even smaller amounts of NCAM containing VASE are present in the endocrine tumor cell lines examined. The latter express polysialylated NCAM, which is found at the cell surface predominantly at the contact sites of these cells. These results led us to conclude that these posttranscriptional and posttranslational modifications of NCAM may modulate the function of NCAMs in endocrine tissues and endocrine tumor cells in a way similar to that observed in other systems.

\section{Acknowledgments}

We would like to thank Annette Christoph (Koln, Germany) for supplying the polyclonal antiserum against the Ig-like domains of NCAM. Drs. G Rougon (Marseille, France) and D. Bitter-Suermann (Hannover, Germany) are gratefully acknowleged for their generous gift of antisera. The authors thank Mrs. M. Rudolf, 1. Urban, and Mr. W. Podschuweit for expert technical assistance.

\section{References}

1. Edelman GM 1988 Morphoregulatory molecules. Biochemistry $27: 3533-3543$

2. Langley K, Gratzl M 1990 Neural cell adhesion molecule NCAM in neural and endocrine cells. In: Gratzl M, Langley K (eds) Markers for Neural and Endocrine Cells. Molecular and Cell Biology, Diagnostic Applications. Verlag Chemie, Weinheim, pp 133-178

3. He H-T, Barbet J, Chaix J-C, Goridis C 1986 Phosphatidylinositol is involved in the membrane attachment of N-CAM-120, the smallest component of the neural cell adhesion molecule. EMBO J 5:24892494

4. He H-T, Finne J, Goridis C 1987 Biosynthesis, membrane association, and release of N-CAM 120, a phosphatidylinositol-linked form of the neural cell adhesion molecule. J Cell Biol 105:2489-2500

5. Hemperly JJ, Edelman GM, Cunningham BA 1986 cDNA clones of the neural cell adhesion molecule ( $\mathrm{N}$-CAM) lacking a membranespanning region consistent with evidence for membrane attachment via a phosphatidylinositol intermediate. Proc Natl Acad Sci USA 83:9822-9826

6. Santoni M-J, Barthels D, Vopper G, Boned A, Goridis C, Wille W 1989 Differentiatial exon usage involving an unusual splicing mechanism generates at least eight types of NCAM CDNA in mouse brain. EMBO J 8:385-392

7. Chen A, Reyes A, Akeson R 1990 Transcription initiation sites and structural organization of the extreme $5^{\prime}$ region of the rat neural cell adhesion molecule gene. Mol Cell Biol 10:3314-3324

8. Hirsch MR, Gaugler L, Deagostini-Bazin H, Bally-Cuif L, Goridis C 1990 Identification of positive and negative regulatory elements governing cell-type-specific expression of the neural cell adhesion molecule gene. Mol Cell Biol 10:1959-1968

9. Murray BA, Owens GC, Prediger EA, Crossin KL, Cunningham BA, Edelman GM 1986 Cell surface modulation of the neural cell adhesion molecule resulting from alternative mRNA splicing in a tissue-specific developmental sequence. J Cell Biol 103:1431-1439

10. Owens GC, Edelman GM, Cunningham BA 1987 Organization of the neural cell adhesion molecule ( $\mathrm{N}$-CAM) gene: alternative exon usage as the basis for different membrane-associated domains. Proc Natl Acad Sci USA 84:294-298

11. Barbas JA, Chaix J-C, Steinmetz M, Goridis C 1988 Differential splicing and alternative polyadenylation generates distinct NCAM transcripts and proteins in the mouse. EMBO J 7:625-632

12. Barthels D, Santoni M-J, Wille W, Ruppert C, Chaix J-C, Hirsch M-R, Fontecilla-Camps JC, Goridis C 1987 Isolation and nucleotide sequence of mouse NCAM CDNA that for a Mr 79,000 polypeptide without a membrane-spanning region. EMBO J 6:907-914

13. Dickson GH, Gower HJ, Barton $\mathrm{CH}$, Prentice $\mathrm{HM}$, Elsom VL, Moore SE, Cox RD, Quinn C, Putt W, Walsh FS 1987 Human muscle cell adhesion molecule (N-CAM): identification of a musclespecific sequence in the extracellular domain. Cell 50:1119-1130

14. Thompson J, Dickson G, Moore SE, Gower HJ, Putt W, Kenimer JG, Barton CH, Walsh FS 1989 Alternative splicing of the neural cell adhesion molecule gene generates variant extracellular domain structure in the skeletal muscle and brain. Genes Dev 3:348-357

15. Reyes AA, Small SJ, Akeson R 1991 At least 27 alternatively spliced forms of the neural cell adhesion molecule mRNA are expressed during rat heart development. Mol Cell Biol 11:16541661

16. Hamshere M, Dickson G, Eperon I 1991 The muscle specific domain of mouse NCAM: structure and alternative splicing patterns. Nucleic Acids Res 19:4709-4716

17. Barthels D, Vopper G, Boned A, Cremer H, Wille W 1992 High degree of NCAM diversity generated by alternative RNA splicing in brain and muscle. Eur J Neurosci 4:327-334

18. Predinger EA, Hoffman S, Edelman GM, Cunningham BA 1988 Four exons encode a 93-basepair insert in three neural cell adhesion molecule mRNAs specific for chicken heart and skeletal muscle. Proc Natl Acad Sci USA 85:9616 9620

19. Small SJ, Shull GE, Santoni M-J, Akeson R 1987 Identification of a cDNA clone that contains the complete coding sequence for a 140-kD rat NCAM polypeptide. J Cell Biol 105:2335-2345

20. Doherty P, Moolenaar CECK, Ashton SV, Michalides RJAM, 
Walsh FS 1992 The VASE exon downregulates the neurite growth promoting activity of NCAM 140. Nature 356:791-793

21. Finne J, Deagostini-Bazin H, Goridis C 1983 Occurence of $\alpha 2-8$ linked polysialosyl units in neural cell adhesion molecule. Biochem Biophys Res Commun 112:482-487

22. Hoffman S, Edelman GM 1983 Kinetics of homophilic binding by $E$ and $A$ forms of the neural cell adhesion molecule. Proc Natl Acad Sci USA 80:5762-5766

23. Rutishauser U, Jessell TM 1988 Cell adhesion molecules in vertebrate neural development. Physiol Rev 68:819-857

24. Regan CM 1991 Regulation of neural cell adhesion molecule sialy lation state. Int J Biochem 23:513-523

25. Rutishauser U, Acheson A, Hall AK, Sunshine J 1988 N-CAM as a regulator for cell-cell interactions. Science 240:53-57

26. Doherty P, Cohen J, Walsh FS 1990 Neurite outgrowth in response to transfected N-CAM changes during development and is modulated by polysialic acid. Neuron 5:209-219

27. Langley OK, Aletsee MC, Gratzl M 1987 Endocrine cells share expression of N-CAM with neurons. FEBS Lett 220:108-112

28. Nybroe O, Gibson A, Miller CJ, Rhode H, Dahlin J, Bock E 1986 Expression of N-CAM polypeptides in neurons. Neurochem Int 9:539-544

29. Langley OK, Aletsee-Ufrecht MC, Grant N, Gratzl M 1989 Expression of neural cell adhesion molecule NCAM in endocrine cells. J Histochem Cytochem 37:781-791

30. Prentice HM, Moore SE, Dickson JG, Doherty P, Walsh FS 1987 Nerve growth factor-induced changes in neural cell adhesion molecule (N-CAM) in PC12 cells. EMBO J 6:1859-1863

31. Yokora K, Furth J, Haran-Ghera N 1961 Induction of mammotrophic pituitary tumors by $X$-rays in rats and mice: the role of mammotropes in development of mammary tumors. Cancer Res $21: 178-186$

32. Greene LA, Tischler AS 1976 Establishment of a noradrenergic clonal line of rat adrenal pheochromocytoma cells which respond to nerve growth factor. Proc Natl Acad Sci USA 73:2424-2428

33. Kaplan B, Bernstein SL, Gioio AE 1979 An improved method for the rapid isolation of bovine ribonucleic acid. Biochem J 183:181184

34. Small SJ, Shull GE, Santoni M-J, Akeson R 1987 Identification of a cDNA clone that contains the complete coding sequence for a 140-kD rat NCAM polypeptide. I Cell Biol 105:2335-2345

35. Saiki RK, Gelfand DH, Stoffel S, Scharf SJ, Higuchi R, Horn GT, Mullis KB, Erlich HA 1988 Primer-directed enzymatic amplification of DNA with thermostable DNA polymerase. Science 239:489491

36. Sambrook J, Fritsch EF, Maniatis T 1989 Molecular Cloning-A Laboratory Manual. Cold Spring Habor Laboratory, Cold Spring Habor

37. Goridis G, Rougon G, Hirn M, Santoni M-J, Gennarini G, Deagostini-Bazin H, Jordan BR, Kiefer M, Steinmetz M 1985 Isolation of mouse N-CAM-related CDNA: detection and cloning using monoclonal antibodies. EMBO J 4:631-635

38. Ruppert C, Goldowith D, Wille W 1986 Proto-oncogene c-myc is expressed in cerebellar neurons at different developmental stages. EMBO J 5:1897-1901

39. Lahr G, Heiss C, Mayerhofer A, Schilling K, Parmer RJ, O'Connor DT, Gratzl M 1990 Chromogranin A in the olfactory system of the rat. Neuroscience 39:605-611

40. Mayerhofer A, Lahr G, Gratzl M 1991 Expression of the neural cell adhesion molecule (NCAM) in endocrine cells of the ovary. Endocrinology 129:792-800

41. Frosch $\mathbf{M}$, Gorgen $\mathrm{I}$, Boulnois GJ, Tïmmis $\mathrm{KN}$, Bitter-Suerman D 1985 NZB mouse system for productioon of monoclonal antibodies to weak bakterial antigens: isolation of an $\operatorname{IgG}$ antibody to the polysaccharide capsules of Escherichia coli K1 and group B meningococci. Proc Natl Acad Sci USA 82:1194-1198

42. Hsu SM, Raine L, Fanger HJ 1981 Use of avidin-biotin-peroxidase $(A B C)$ in immunoperoxidase technique: a comparison between $A B C$ and unlabeled antibody (PAP) procedures. J Histochem Cytochem $29: 577-580$

43. Rougon G, Marshak DR 1986 Structure and immunological characterization of the amino-terminal domain of mammalian neural cell adhesion molecules. J Biol Chem 261:3396-3401

44. Aletsee-Ufrecht MC, Langley OK, Gratzl O, Gratzl M 1990 Differential expression of the neural cell adhesion molecule NCAM 140 in human pituitary tumors. FEBS Lett $272: 45-49$

45. Aletsee-Ufrecht MC, Langley $\mathrm{OK}$, Rotsch $\mathrm{M}$, Havemann K, Gratzl M 1990 NCAM: a surface marker for human small cell lung carcinoma cells. FEBS Lett 267:295-300

46. Landmesser L, Dahm L, Tang J, Rutishauser U 1990 Polysialic acid as a regulator of intramuscular nerve branching during embryonic development. Neuron 4:655-667

47. Edelman GM, Chuong CM 1982 Embryonic to adult conversion of neural cell adhesion molecules in normal and staggerer mice. Proc Natl Acad Sci USA 79:7036-7040

48. Small S], Akeson R 1990 Expression of the unique NCAM VASE exon is independently regulated in distinct tissues during development. J Cell Biol 111:2089-2096

49. Williams AF Barclay AN 1988 The immunoglobulin superfamily: domains for cell surface recognition. Annu Rev Immunol 6:381-405

50. Moos M, Tacke R, Scherer H, Teplow D, Früh K, Schachner M 1988 The neural adhesion molecule $L 1$ is a member of the immunoglobulin superfamily and shares binding domains with fibronectin. Nature 334:701-703

51. Powell SK, Cunningham BA, Edelman GM, Rodriguez-Boulan $\mathrm{E}$ 1991 Targeting of transmembrane and GPI-anchored forms of $\mathrm{N}$ CAM to opposite domains of a polarized epithelial cell. Nature 353:76-77

52. Pollerberg GE, Burridge K, Krebs KE, Goodman SR, Schachner M 1987 The $180-\mathrm{kD}$ component of neural cell adhesion molecule N-CAM is involved in cell-cell contacts and cytoskeleton-membrane interactions. Cell Tissue Res 250:227-236

53. Pollerberg GE, Sadoul R, Goridis C, Schachner M 1985 Selective expression of the $180 \mathrm{kD}$ component of neural cell adhesion molecule N-CAM during development. J Cell Biol 101:1921-1929

54. Edelman GM 1985 Cell adhesion and molecular processes of morphogenesis. Annu Rev Biochem 54:135-169

55. Theodosis DT, Rougon G Poulain DA 1991 Retention of embryonic features by an adult neuronal system capable of plasticity: polysialylated neural cell adhesion molecule in the hypothalamoneurohypophysial system. Proc Natl Acad Sci USA 88:5494-5498

56. Rougon G, Dubois C, Buckley N, Magnani L, Zollinger W 1986 A monoclonal antibody against meningococcus group $B$ polysaccharide distinguises embryonic from adult N-CAM. J Cell Biol 103:2429-2437

57. Bitter-Suermann D, Roth J 1987 Monoclonal antibodies to polysialic acid reveal epitope sharing between invasive pathogenic bacteria, differentiating cells and tumor cells. Immunol Res 6:225-237

58. Frawley LS, Boockfor FR 1991 Mammosomatotropes: presence and functions in normal and neoplastic pituitary tissue. Endocr Rev $12: 337-355$

59. Poltorak M, Shimoda K, Freed WJ 1990 Cell adhesion molecules (CAMs) in adrenal medulla in situ and in vitro: enhancement of chromaffin cell L1/Ng-CAM expression by NGF. Exp Neurol $110: 52-72$

60. Nussdorfer GG 1986 Cytophysiology of the adrenal cortex. Int Rev Cytol 98:319-381 